\title{
WSPÓŁCZESNE RUCHY KONTESTACYJNE W KOŚCIELE KATOLICKIM AUSTRII I RFN
}

Kojarzone z postacią Marcina Lutra Niemcy są także współcześnie krajem o dużej dynamice życia religijnego. Dziedzictwo Reformacji oraz różnicowanie wpływów dynastycznych Habsburgów i Hohenzollernów, z aktualną do dziś linią Menu, rozdzielającą katolickie południe i protestancką północ, stanowią historyczną bazę procesów związanych z religijnością, a wpływających na intelektualny i ustrojowy wymiar życia społecznego Niemiec. Czynnikiem rozstrzygającym o niemieckiej specyfice relacji między władzą świecką a sferą religii była tradycyjnie silna pozycja Kościoła, sięgająca czasów Ottona I oraz roli ówczesnego duchowieństwa w umocnieniu władzy cesarskiej. Tak ukształtowanej pozycji Kościoła rzymskiego nie zdołały istotnie osłabić nawet późniejsze ruchy reformacyjne. Tym z kolei, jako narzędziom - w pierwotnym zamyśle - odnowy i umocnienia Kościoła, mimo dokonanych rozłamów, nie sposób odmówić roli katalizatorów refleksji nad tożsamością wspólnoty religijnej oraz jej relacji z otoczeniem. Wreszcie istotnym elementem formującym rolę Kościołów w życiu społecznym i państwowym Niemiec oraz Austrii są sięgające pierwszej połowy XIX wieku tradycje politycznego zaangażowania chrześcijan. Ich odbicie znajdujemy nie tylko w działalności organizacji i stronnictw politycznych chrześcijańskiej demokracji, lecz i w refleksji intelektualnej dotyczącej form oraz granic zaangażowania politycznego pomiędzy sferą religii a racją stanu. Dające się precyzyjnie umiejscowić w latach trzydziestych XIX stulecia początki politycznego zaangażowania katolików niemieckich wynikały ni mniej ni więcej, ale z konieczności obrony swobód religii i zagwarantowanych wcześniej praw w zakresie zawierania małżeństw, podważanych przez rząd pruski. Zainicjowany wówczas ruch spowodował powstanie wielu stowarzyszeń, związków oraz czasopism wraz z ich zapleczem intelektualnym, co zdeterminowało bodaj najistotniejszą cechę niemieckiego katolicyzmu politycznego - tkwiącą u jego genezy inicjatywę oddolną 
laikatu1 ${ }^{1}$ Późniejsze doświadczenia z okresu Kulturkampfu utwierdziły tę drogę aktywności publicznej. Dramatyczne lata narodowego socjalizmu, a także zagrożenie ideologią materialistyczną w Niemieckiej Republice Demokratycznej zmusiły do obrony racji chroniących elementarne prawa i wolności w oparciu o prawo naturalne i dwudziestowieczny katalog praw człowieka.

Istotne w tym miejscu jest zastrzeżenie dotyczące ryzyka instrumentalnej interpretacji przesłania wiary $\mathrm{w}$ formie narzędzia politycznego. Zagubienie perspektywy transcendentnej prowadzi do prób bezpośredniego, dosłownego zastosowania jej nakazów w życiu społeczności i pragmatyce politycznej. Nietrudno w ten sposób uczynić z przesłania wiary, nakierowanego na perspektywę eschatologiczną, narzędzia walki, czy zgoła rewolucji. Religia staje się $\mathrm{w}$ tym ujęciu narzędziem wyzwolenia $\mathrm{z}$ niesprawiedliwości "tu i teraz", zatracając swą wertykalną naturę; przestaje być poszukiwaniem wspólnego dobra, dostarcza raczej argumentów do usuwania wszystkiego, co nie odpowiada założonemu celowi wyzwolenia z doczesnych ograniczeń. Pułapka, której najbardziej znanym przykładem w ostatnich dziesięcioleciach stała się teologia wyzwolenia w krajach Ameryki Łacińskiej, pozostaje aktualną przestrogą. Redukuje ona wiarę do poziomu ideologii i zamyka jej odniesienie do wolności i godności osoby ludzkiej oraz wielości sposobów urzeczywistnia chrześcijaństwa. Ideologiczne próby zaprowadzenia przyszłego porządku w życiu doczesnym mogą być tylko ślepą uliczką, prowadzącą do wykrzywienia przekazu wiary oraz poważnego naruszenia ładu.

Wypracowany w RFN po II wojnie światowej model ustroju demokratycznego opierał się na fundamencie państwa prawa oraz zasady wolności i nienaruszalnej godności osoby ludzkiej. Znalazło to odzwierciedlenie w pierwszych artykułach Ustawy Zasadniczej z 1949 r., a w praktyce politycznej w programie chrześcijańskiej demokracji, która pod wieloletnim, charyzmatycznym przywództwem Konrada Adenauera kształtowała ład państwowy i społeczny Zachodnich Niemiec. Co jednak dziś może wydawać się zaskakujące, powojenna konstytucja RFN nie została dobrze przyjęta przez hierarchię katolicką nad Renem. Biskupi zarzucali projektowanemu dokumentowi brak pogłębionego ujęcia religijnego źródła przyjętych zasad i traktowali go jako tymczasowy. Podobnie wcale nie był oczywisty wybór modelu zaangażowania świeckich w życie publiczne młodej republiki; projektowano przyjęcie modelu Akcji Katolickiejjako sieci stowarzyszeń kierowanych przez duchowieństwo. Samoistne odradzanie się funkcjonujących wcześniej ruchów i instytucji świeckich przekreśliło

${ }^{1}$ Por. J. Gowin, M. Spieker, Zaangażowanie czy defensywa? Katolicy w życiu politycznym Polski i Niemiec, Warszawa 1997, s. 65-66. 
te plany, podtrzymując tym samym żywe w niemieckim katolicyzmie tradycje reprezentacji i działalności laikatu. Podkreślić należy, że proces ten nie stanowił płynnego przejścia ponad dwunastoletnim okresem dyktatury narodowosocjalistycznej i nie stanowił prostej kontynuacji działań przerwanych w 1933 r. $^{2}$ Wyzbycie się przez państwo zwierzchności nad Kościołami wymuszało ułożenie relacji z nimi na nowych zasadach, co w przypadku Kościoła katolickiego oznaczało modyfikację istniejących oraz zawarcie nowych konkordatów przez poszczególne kraje federacji. W rezultacie Republika Federalna Niemiec stała się rzadkim we współczesnych relacjach międzynarodowych przykładem państwa o bogatym instrumentarium umów ze Stolicą Apostolską, poczynając od najstarszego konkordatu bawarskiego z 1924 r., przez funkcjonujący nadal w obiegu prawnym konkordat Rzeszy z 1933 r., aż po datujące się na okres po zjednoczeniu Niemiec konkordaty z Saksonią (1996), Turyngią i Meklemburgią Pomorzem Przednim (1997), Saksonią Anhalt (1998), Brandenburgią i Bremą (2003), Hamburgiem (2005) oraz Szlezwikiem-Holsztynem (2009).

Pośrednią formą współpracy między Kościołami a organami państwa stały się biura katolickie utworzone w 1951 r. w Bonn, a później także przy siedzibach władz krajów federacji, służące bieżącej koordynacji działań na styku organów i instytucji państwowych oraz kościelnych. Nie stanowią one oficjalnej, ani tym bardziej politycznej reprezentacji katolicyzmu, jednak istotnie ułatwiają i wspomagają bieżącą współpracę. Na marginesie można dodać, że podobny model reprezentacji i współpracy wykorzystany został przez instytucje Kościoła katolickiego działające przy Wspólnotach Europejskich: datujące się od 1956 r. Katolickie Biuro Informacji i Inicjatyw Europejskich (OCIPE), a także Komisję Episkopatów Wspólnot Europejskich (COMECE).

Wielość oznacza bogactwo form i środków nie tylko w dziedzinie regulacji prawnych. Organizacje katolików świeckich w Niemczech, niejednokrotnie legitymujące się bardzo długimi, sięgającymi pierwszej połowy XIX wieku tradycjami, zrzeszone są w Centralnym Komitecie Katolików Niemieckich (Zentralkomitee der deutschen Katholiken - ZdK). Geneza tego związku sięga pierwszego Katholikentagu i roku 1848, a jego dynamiczny rozwój w kolejnych dekadach XIX stulecia podyktowany był relacjami wyznaniowymi oraz zadaniami stawianymi przed organizacjami katolickimi przez życie społeczne, gospodarcze oraz zmienność koniunktury politycznej, czego najjaskrawszym przykładem był wspomniany już okres Kulturkampfu. Współcześnie ZdK odrodził się po pierwszym powojennym Katholikentagu w 1948 r. i funkcjonuje w sformalizowanych ramach od 1952 r. Jego statut zmodyfikowano w duchu

\footnotetext{
${ }^{2}$ Por. ibidem.
} 
reform II Soboru Watykańskiego oraz krajowego synodu z Würzburga, który implementował Sobór w realia i prawodawstwo Kościoła w Zachodnich Niemczech. Zadaniem $Z d K$ jest koordynowanie na szczeblu ponaddiecezjalnym prac organizacji laikatu katolickiego. Najwyższym organem Komitetu jest zgromadzenie ogólne, skupiające dziś ok. 230 członków wybieranych przez rady diecezjalne, delegowanych przez organizacje oraz wyłanianych drogą głosowania osobistości. Na podkreślenie zasługuje podwójna legitymizacja Komitetu: prócz demokratycznego mechanizmu konstytuowania zgromadzenia ogólnego stanowi ją także uznanie przez Niemiecką Konferencję Biskupów.

Długie tradycje $Z d K$ dowodzą aktywności organizacji i stowarzyszeń katolików świeckich w zróżnicowanych okolicznościach ostatnich stuleci, a także ich zdolności adaptacyjnych. Nawet powojenne dekady były czasem ewolucji wynikłej ze zmian w kulturze politycznej Niemiec oraz rewolucji, jaką bez wątpienia dla Kościoła powszechnego były konsekwencje Soboru Watykańskiego II. Model politycznego katolicyzmu czasów Konrada Adenauera był poręczeniem dla powstającej demokracji bońskiej, a faktyczne zaangażowanie polityków przyznających się do chrześcijańskiej inspiracji pozwoliło nie tylko zbudować fundamenty państwowości Niemiec Zachodnich, ale również poczynić pierwsze kroki w procesie integracji gospodarczej i politycznej Wspólnot Europejskich. Unikalne na tle wcześniejszych epok, a co ważniejsze, efektywnie wykorzystane wpływy katolickiej opinii oraz poparcie udzielane przez długie lata partiom chadeckim, w kluczowy sposób przyczyniły się do konsolidacji państwa. Z drugiej strony, mimo późniejszej krytyki i kontestacji, z jaką spotkał się katolicyzm w latach sześćdziesiątych i siedemdziesiątych, rola odegrana przezeń w czasach Adenauera oceniana jest - zdaniem teologa, pierwszego dyrektora Akademii Katolickiej w Bawarii i sekretarza Niemieckiej Konferencji Biskupów Karla Forstera - mianem antycypacji wypracowanego przez Vaticanum II modelu obecności Kościoła w świecie - jako obrońcy sprawiedliwości i poszanowania godności osoby ludzkiej, służącego społeczności ludzkiej w wielorakich potrzebach i troskach ${ }^{3}$.

Krytyka katolicyzmu u schyłku lat sześćdziesiątych była wypadkową ówczesnej atmosfery rozliczeń z przeszłością; wysuwano zarzuty uległości wobec narodowego socjalizmu czy dążenia do odbudowy autorytarnego państwa. Także zmiany prawodawcze, zwłaszcza w dziedzinie ochrony rodziny i życia ludzkiego, wprowadzone przez rządzącą od 1969 r. koalicję $S P D$ i FDP stały się zarzewiem sporów, z których katolicyzm nie wyszedł obronną ręką. Równolegle trwający w samym Kościele proces recepcji

${ }^{3}$ Opinia Karla Forstera przytoczona w: J. Gowin, M. Spieker, Zaangażowanie czy defensywa..., op. cit., s. 97. 
nauczania Soboru Watykańskiego II kierował uwagę hierarchów oraz świeckich na kwestie odnowy i takiego usytuowania Kościoła we współczesności, które gwarantowałoby aktualność przekazu w zmieniającej się dynamice otoczenia. Pilnie potrzebne było aggiornamento - dostosowanie do nowoczesności, uznające m.in. pluralizm wyznaniowy i światopoglądowy, ale i niezbędne poszanowanie granic wyznaczonych przez prawo naturalne. Przeniesienie dyskusji na tak fundamentalne tematy $\mathrm{z}$ auli soborowej na poziom Kościoła lokalnego i wspólnot parafialnych czy organizacji laikatu nie było wolne od pułapek nadinterpretacji i błędów. Perspektywa czasu pozwala na sformułowanie nieco paradoksalnej oceny tego okresu; zepchnięty do defensywy na płaszczyźnie politycznej, katolicyzm niemiecki skoncentrował swą uwagę na szansach wynikających z reform soborowych. Nie pierwszy raz potwierdziło to prawdę o religii znajdującej korzystne impulsy dla swego rozwoju w sytuacji zdystansowania wobec władzy świeckiej. W warunkach niemieckich oznaczało to przede wszystkim położenie nacisku na dialog ekumeniczny. Wspólne stanowisko Kościoła katolickiego i konfesji ewangelickich zrzeszonych w Kościele Ewangelickim w Niemczech $(E K D)$ w sprawie reform prawa rodzinnego i karnego, sformułowane w 1970 r. było jednym z pierwszych, w których fundamentalne zasady chrześcijańskie stwarzały płaszczyznę do dialogu z państwem i jego instytucjami ${ }^{4}$.

Zmiana koalicji rządowej w 1982 r., nie była już - co oczywiste - powrotem do epoki Adenauera i ojców-założycieli zjednoczonej Europy. Uznanie przez partie rządzącą chrześcijańskich imponderabiliów nie usunęło z drogi kierowanych przez Helmuta Kohla kolejnych gabinetów dwuznaczności etycznych epoki schyłku zimnej wojny czy rzeczywistości państwa, w którym religie, a zwłaszcza katolicyzm, ulegały coraz większej marginalizacji. Nieprzystawalność kategorii konfesyjnych do oceny rzeczywistości unaoczniła choćby prognoza, że Niemcy po zjednoczeniu w 1990 r. będą bardziej protestanckie; przyłączenie pięciu wschodnich krajów federacji wraz z zaawansowaniem procesu sekularyzacji zachodnich regionów sprawiło, że Niemcy zjednoczone okazały się raczej bardziej ateistyczne - $\mathrm{i}$ to nie na gruncie dialektycznym, lecz praktycznym.

Innym istotnym czynnikiem kształtującym miejsce religii $\mathrm{w}$ życiu społecznym oraz relacjach z państwem są zmiany w obrębie islamu w Niemczech. Religia wyznawców Proroka, która współcześnie pojawiła się nad Renem $\mathrm{w}$ wyniku zawartych $\mathrm{w}$ pierwszej połowie lat sześćdziesiątych z Turcją, Marokiem i Tunezją umów o możliwości zatrudnienia migrantów, wpłynęła na statystyki życia religijnego, ale i na pogłębienie refleksji oraz działań na płaszczyźnie relacji z państwem. W 1987 r. w Niemczech

${ }^{4}$ Por. J. Gowin, M. Spieker, Zaangażowanie czy defensywa..., op. cit., s. 103-104. 
zamieszkiwało 1,65 miliona muzułmanów, po kolejnych 16 latach ich liczba się podwoiła, a obecnie wynosi około 4 milionów osób, spośród których 45 procent posiada obywatelstwo niemieckie ${ }^{5}$. Ogrom kwestii związanych z migracją i zakorzenieniem zróżnicowanej pod względem narodowościowym i kulturowym grupy stanowi odrębny kompleks zagadnień. Z punktu widzenia niniejszych rozważań istotny jest wpływ obecności muzułmanów na artykułowanie kwestii roli i miejsca religii w funkcjonowaniu państwa i społeczeństwa. Spory dotyczące obecności symboli religijnych czy manifestowania odrębnej tożsamości kulturowej w przestrzeni publicznej, implementacja powszechnie obowiązujących przepisów prawa w odniesieniu do specyfiki jednostek i społeczności muzułmańskich, czy wreszcie dyskusje o religijnych inspiracjach w procesie integracji europejskiej nabrały innego wymiaru w perspektywie obecności islamu w Niemczech. Przełamanie utartych schematów postrzegania Niemiec jako kraju dzielonego między protestantów i katolików stało się koniecznością, nie tylko w codziennych zabiegach na rzecz poszanowania odmienności i akceptacji innego-obcego, ale także w funkcjonowaniu instytucji państwa oraz organizacji społecznych.

Schyłek katolicyzmu politycznego, okres kontestacji przełomu lat sześćdziesiątych i siedemdziesiątych, zaawansowane procesy laicyzacji oraz fundamentalne zmiany na mapie życia religijnego w Niemczech zjednoczonych stanowią tło dla rozwoju ruchów oddolnych formułujących radykalne postulaty reformy instytucji Kościoła rzymsko-katolickiego oraz jego nauczania.

\section{Kirche von unten}

Jedną z pierwszych inicjatyw omawianej natury była sieć ekumeniczna Kościół oddolny (Ökumenisches Netzwerk Initiative Kirche von unten), która rozpoczęła sformalizowaną działalność w 1980 r. w reakcji na przebieg debat podczas wcześniejszego Katholikentagu we Freiburgu w 1978 r. Z myślą o kolejnym zgromadzeniu, zaplanowanym na 1980 r. w Berlinie, podjęto krytyczne dyskusje dotyczące polaryzacji wewnętrznej Kościoła w RFN. Ponieważ nie znalazły one zgodnego z zamysłami inicjatorów odzwierciedlenia podczas berlińskiego spotkania, doszło do zawiązania inicjatywy „oddolnego Katholikentagu" - spotkania około 30 grup reprezentujących

${ }^{5}$ P. Hünseler, Deutschlands Muslime. Eine religionssoziologische Bestandsaufnahme, w: Die unbekannte Religion. Muslime in Deutschland, Herder Korrespondenz Spezial, Freiburg i. Br. 2009, s. 2; Evangelisch-Lutherische Kirche in Bayern (Hg.), Erste Schritte wagen. Eine Handreichung für die Begegnung von Christen mit ihren muslimischen Nachbarn, München 2009, S. 15. 
pogląd o potrzebie rzeczywistego wdrożenia reform Soboru Watykańskiego II w Kościele. Punktem zapalnym dla niemieckich zwolenników takiej tezy była encyklika Pawła VI Humanae vitae z 1968 r., potwierdzająca nauczanie soboru na temat życia małżeńskiego oraz etyki seksualnej. Obok kwestii relacji między hierarchią a laikatem, celibatu oraz postulatu demokratyzacji Kościoła, sprawy etyki seksualnej były zasadniczymi problemami koncentrującymi uwagę ruchów kontestacyjnych. Inicjatywa Kirche von unten była także aktywna na płaszczyznach charakterystycznych dla lewicowych inicjatyw pokojowych lat osiemdziesiątych. Artykułowała swoje postulaty przy okazji manifestacji pokojowych, a także podczas organizowanych pod własnymi auspicjami spotkań, np. w 1981 r. w Düsseldorfie pod hasłem „Praca na rzecz pokoju jako zadanie społeczno-polityczne i kościelne", czy zorganizowanej w tym samym roku demonstracji w Bonn, na którą zaproszono około 500 organizacji społecznych i politycznych $^{6}$. Protesty przeciwko instalacji na terenie RFN broni atomowej średniego zasięgu (np. łańcuch ludzki, jaki połączył w 1983 r. Stuttgart i Ulm), dyskusje związane ze święcącą w latach osiemdziesiątych triumfy teologią wyzwolenia, czy poparcie dla działalności marginalizowanej partii Zielonych mieszały się $\mathrm{w}$ działaniach Kirche von unten $\mathrm{z}$ autonomicznymi "Katholikentagami oddolnymi”, toczącymi się równolegle do tych oficjalnych, kontaktami z Kościołami protestanckimi czy kontestowaniem decyzji personalnych, np. obsady arcybiskupstwa w Kolonii przez bpa Joachima Meissnera z Berlina.

W drugiej połowie lat osiemdziesiątych ruch Kirche von unten we współpracy z przedstawicielami Kościołów protestanckich zaangażował się w dyskusje towarzyszące Europejskiemu Zgromadzeniu Ekumenicznemu $\mathrm{w}$ Bazylei, które odbyło się na zaproszenie Konferencji Kościołów Europejskich (KEK) oraz Rady Konferencji Episkopatów Europy (CCEE). Idee ekumeniczne przywoływane są do dziś wśród głównych wyznaczników ruchu, choć nadane im znaczenie wybiega poza rozumienie eklezjalne, obejmując także dialog międzykulturowy. Zwraca uwagę, że ponad wspólnotowość wynikającą z natury Kościoła przedkładane są postulaty poprawy losu najuboższych mieszkańców opanowanego przez gospodarkę neoliberalną globu. W praktycznym wymiarze znajduje to odzwierciedlenie w projektach z zakresu pomocy rozwojowej adresowanych do krajów Ameryki Łacińskiej. Krytyczny dialog z instytucjami kościelnymi traktowany jest jako równoważny z relacjami ze sprawującymi władzę podmiotami politycznymi. Solidarność z najsłabszymi jest argumentem legitymizującym oczekiwania powrotu Kościoła do duchowości pierwotnej wspólnoty, co przekłada się na dość egzotycznie brzmiące hasło

\footnotetext{
${ }^{6}$ Kleine Kirchengeschichte von unten, http://alt.ikvu.de/html/kontexte/geschichte.html
} 
działań na rzecz praw człowieka w Kościele oraz oferowaniu doradztwa i pomocy w przypadkach dyskryminacji w Kościele. Sama organizacja jest siecią łączącą małe wspólnoty, gminy i parafie, redakcje czasopism oraz mniejsze organizacje. Ich reprezentanci gromadzą się na dorocznym Spotkaniu Delegatów, podczas którego dyskutowane są kwestie bieżące, strategie oraz przygotowania kolejnych Katholikentagów i ewangelickich Kirchentagów. Walny zjazd dokonuje również wyboru na dwuletnią kadencję prezydium oraz rzecznika, reprezentujących organizację na forum publicznym. Od 2012 r. funkcję przewodniczącego sprawuje Bernd Hans Göhrig, 46-letni absolwent filozofii, politologii oraz teologii katolickiej, zaangażowany wcześniej w stowarzyszeniu Katolickiej Młodzieży Studenckiej (KSJ) diecezji Freiburg. W skład pięcioosobowego prezydium wchodzi również pastor ewangelicki dr Herbert Koch, dwóch młodych działaczy ewangelickich, pracownik naukowy oraz ogrodnik będący członkiem Związku Religijnych Socjalistów w Niemczech (BRSD) - organizacji powołującej się na tradycje sięgające 1919 r. ${ }^{7}$ Siedzibą władz Kirche von unten jest dom im. Oskara Romero w Bonn.

\section{Austriacki ruch Kirchenvolks-Begehren Wir sind Kirche}

W odróżnieniu od Kirche von unten, którego geneza była charakterystyczna dla powiązanej z zainteresowaniem amerykańską teologią wyzwolenia atmosfery ideowej lat osiemdziesiątych, pojawienie się kolejnych organizacji krytycznych wobec struktury oraz nauczania Kościoła katolickiego w Austrii i Niemczech związane było z kryzysem jego autorytetu oraz nagłośnionymi skandalami obyczajowymi bądź ich poszlakami. Nagromadzenie tych zdarzeń, przybierające formę narastającej fali, odnosiło się często do zadawnionych spraw, było zapalnikiem uruchamiającym krytykę instytucji kościelnych oraz postulaty zmian sposobu i form ich funkcjonowania. Tak było w Austrii, gdzie opublikowane 27 marca $1995 \mathrm{r}$. w czasopiśmie „Profil” wyznania 37-letniego dawnego wychowanka seminarium męskiego w Hollabrun zawierały zarzuty wykorzystywania seksualnego pod adresem rektora, spowiednika i wykładowcy, a w momencie publikacji arcybiskupa Wiednia, kard. Hansa Hermanna Gröera. Choć sprawa nie została do końca wyjaśniona, także z powodu przedawnienia, a kardynał nie przyznał się do zarzucanych mu czynów, w ciągu pół roku jego urząd został obsadzony przez następcę. Wywołany sprawą Gröera wstrząs w Kościele oraz wśród opinii publicznej wykroczył daleko

\footnotetext{
${ }^{7}$ Patrz: http://www.ikvu.de/kontakt/leitungsteam.html
} 
poza związane z nią okoliczności, obnażając kryzys autorytetu Kościoła oraz stworzył warunki do wyartykułowania postulatów zmian. Zaskakujące było tempo wydarzeń, świadczące nie tylko o randze sprawy wiedeńskiego metropolity, lecz przede wszystkim o dojrzewających od dawna problemach z akceptacją struktur i nauczania Kościoła wśród austriackich katolików.

Podczas zwołanej 14 kwietnia 1995 r. w Innsbrucku konferencji prasowej troje inicjatorów: dr Thomas Plankensteiner, dr Martha Heizer oraz Bernadette Wagnleithner poinformowało o zawiązaniu ruchu Żądania Ludu (Kirchenvolks-Begehren). W ciągu następnych tygodni przedstawiciele wspólnot i środowisk podzielających stanowisko inicjatorów uzgodnili zasadnicze postulaty oraz hasła ruchu i podjęli akcję zbierania podpisów poparcia. 5 lipca 1995 r. ogłoszono zgromadzenie ponad 505 tys. podpisów z Austrii, a także ponad 4 tys. z 31 krajów na 5 kontynentach. Manifest został przekazany biskupowi Johannowi Weberowi, przewodniczącemu Konferencji Biskupów Austrii. Kontynuowano gromadzenie podpisów, także poza granicami Austrii: w diecezjach Niemiec oraz Południowego Tyrolu, jak również Francji, Włoch, Hiszpanii, Belgii, Holandii oraz Stanów Zjednoczonych i Kanady. W grudniu 1995 r. powstający ruch opublikował pierwszy dokument programowy na temat etyki seksualnej, a w styczniu następnego roku wspólnie $\mathrm{z}$ niemieckim ruchem Kirchen Volks Bewegnung został uhonorowany w Tybindze nagrodą im. Herberta Haaga za działalność na rzecz wolności w Kościele. Adresowany w tym samym czasie do papieża list otwarty z prośbą o spotkanie pozostał bez odpowiedzi. Formalne ukonstytuowanie ogólnokrajowej platformy ruchu, który przyjął nazwę Jesteśmy Kościołem (Wir sind Kirche) nastąpiło 24 marca 1996 r. w Salzburgu. Pierwszym przewodniczącym inicjatywy został wybrany dr Thomas Plankensteiner. Dwa lata później zastapił go dr Hubert Feichtlbauer. Kolejnymi przewodniczącymi byli Ingrid Thurner oraz Peter Hurka (od 2004 r.).

W tym samym roku, w dniach 23-24 listopada, doszło do międzynarodowego spotkania przedstawicieli organizacji kontestacyjnych w Rzymie, podczas którego powołano Międzynarodowy Ruch Jesteśmy Kościołem (International Movement We are Church - IMWAC), w którego zespole koordynacyjnym znalazł się Thomas Plankensteiner oraz pochodząca także z Austrii Elfriede Harth, której powierzono funkcję rzeczniczki. IMWAC szczyci się posiadaniem swoich agend w ponad 25 krajach, wśród których wymienia: Belgię, Danię, Niemcy, Finlandię, Francję, Wielką Brytanię, Włochy, Irlandię, Hiszpanię, Holandię, Norwegię, Szwecję, Portugalię oraz Australię, Kanadę, Chile, Meksyk, Republikę Południowej Afryki, Brazylię i Stany Zjednoczone. Niewątpliwie oddźwięk, z jakim spotkały się, zwłaszcza $\mathrm{w}$ pierwszych latach funkcjonowania, hasła wyartykułowane przez 
Wir sind Kirche, spotkał się z echem w wielu krajach, jednak ocena zasięgu ruchu w kategorii globalnej zdaje się być znacznie przeszacowana ${ }^{8}$. Pod względem organizacyjnym i programowym pozostał najsilniej związany z niemieckojęzycznymi krajami europejskimi. IMWAC jest platformą kontaktu z podobnymi organizacjami, m.in. we Francji czy Wielkiej Brytanii, które jednak wyrosły na gruncie wcześniejszej krytyki, sięgającej jeszcze reakcji na opublikowanie encykliki Humanae vitae Pawła VI (Catholics for a Changing Church, wcześniej Catholic Renewal Movement).

Realizowana w Austrii intensywna akcja propagująca ruch Wir sind Kirche zaowocowała zebraniem w ciągu pierwszych pięciu lat jego funkcjonowania ok. 1300 stałych członków. Mimo zapewnień, iż gwarantuje to samofinansowanie i niezależność materialną, a liczba członków systematycznie powiększa się, dane za 2011 r. wskazują na ok. 1500 członków.

Program i cele działalności Wir sind Kirche naszkicowane we wspomnianym pierwszym manifeście z 1995 r., koncentrują się wokół pięciu haseł:

1. Tworzenie Kościoła braterskiego, opartego na równouprawnieniu wierzących i przełamaniu dystansu dzielącego duchowieństwo i świeckich. Realizacja tego warunku umożliwi pełne korzystanie z wielości i różnorodności talentów, w jakie wyposażeni są wszyscy wierni. Elementem takiej wizji Kościoła jest udział całej wspólnoty w podejmowaniu decyzji o obsadzie urzędów biskupich i powierzanie ich tym, którzy cieszą się zaufaniem wspólnoty.

2. Pełne równouprawnienie kobiet w Kościele; możliwość wypowiadania się i decydowania we wszystkich gremiach kościelnych, prawo podejmowania stałego diakonatu, dostęp do kapłaństwa oraz urzędów kościelnych. Wykluczenie możliwości sprawowania urzędów kościelnych przez kobiety nie znajduje, zdaniem Wir sind Kirche, uzasadnienia w Biblii.

3. Swoboda wyboru formy życia w celibacie lub poza celibatem. Celibat związany z urzędem kapłańskim nie wynika z przekazu biblijnego czy dogmatów, lecz z rozwoju historycznego i jako taki podlegać może zmianie. Ważniejsze od tych uregulowań prawnokanonicznych jest prawo wspólnoty do celebrowania Eucharystii i posiadania duchowego przewodnika.

4. Dowartościowanie seksualności jako istotnego elementu natury ludzkiej, stworzonej i aprobowanej przez Boga: uznanie autonomii odpowiedzialnych rozwiązań $\mathrm{w}$ zakresie etyki seksualnej (m.in. regulacja poczęć), przy równoczesnym odrzuceniu znaku równości pomiędzy regulacją poczęć a aborcją; opowiedzenie się za „bardziej ludzką" - nie

${ }^{8}$ Patrz: IMWAC - 15th Anniversary, http://www.we-are-church.org/joomla/index. php?option=com_content\&view $=$ article\&id $=46$ :imwac-15th-anniversary\&catid=12:imwacnews\&Itemid $=21$ 
automatyczną oceną postaw i zachowań, np. w kwestii relacji przedmałżeńskich lub homoseksualnych; odejście od przywiązywania nadmiernej wagi do etyki seksualnej na rzecz podkreślenia innych istotnych tematów, np. pokoju, sprawiedliwości społecznej, wartości stworzenia.

Przekaz orędzia radości zamiast ograniczeń i gróźb: zastąpienie obciążonych sankcjami i zakazami norm duchem solidarności oraz nacechowaną pomocą i zachętą obecnościa, zrozumieniem oraz gotowością pojednania $\mathrm{w}$ relacjach $\mathrm{z}$ ludźmi, którzy znaleźli się $\mathrm{w}$ trudnych sytuacjach, a pragną odnowić swoje życie (np. rozwiedzeni zawierający ponowny związek małżeński czy pozbawieni urzędu księża).

Ruch deklaruje, że swoje postulaty, jak również służącą ich realizacji argumentację czerpie z pierwotnych źródeł religii: Ewangelii, tradycji biblijnej i wynikającego z niej nauczania oraz magisterium Soboru Watykańskiego II. Obok nich wymienia jednak dwa inne punkty orientacyjne: potrzeby ludzkie oraz sumienie, co w przełożeniu na konkretne kwestie diametralnie odwraca sposób diagnozowania zjawisk i aplikację środków zaradczych.

\section{Niemiecki odłam Wir sind Kirche oraz zbuntowani teologowie}

Funkcjonujący w Niemczech Kościelny Ruch Ludowy Jesteśmy Kościołem (Kirchen Volks Bewegung Wir sind Kirche) datuje swoją historię od 1995 r. Reakcja na wiedeńską sprawę Gröera obudziła i nad Renem nadzieje, że możliwe są zmiany w funkcjonowaniu kościelnych struktur oraz nauczaniu zgodne z oczekiwaniami wielu ludzi, którym trudno przyjąć obowiązującą wykładnię. Przyczyn słabości Kościoła katolickiego dopatrywano się w rzekomym zahamowaniu przez papieża Jana Pawła II reform Kościoła zainicjowanych na Soborze Watykańskim II. Wykładnia soborowej spuścizny $\mathrm{w}$ duchu demokratyzacji struktur kościelnych oraz liberalizacji wielu kwestii etycznych, nie wytrzymujących jakoby konfrontacji ze współczesnymi realiami, stanowić miała antidotum na krytykę oraz wystąpienia z Kościoła, które dzięki obowiązującym w Niemczech rozwiązaniom prawnym są wymiernym i wrażliwym wskaźnikiem społecznego usytuowania wspólnot wyznaniowych. Bezpośrednio po powstaniu ruchu Wir sind Kirche w Austrii, jego grupy inicjatywne zawiązane zostały w Dreźnie, Dortmundzie oraz Hanowerze ${ }^{9}$, a jesienią tego samego roku prowadzono w Niemczech akcję gromadzenia podpisów popierających postulaty sformułowane przez założycieli ruchu. W ciągu dwóch miesięcy

${ }^{9}$ T. Mirończuk, Wpływ ruchu „Wir sind Kirche” na rozwój dialogu wewnątrzkościelnego w Austrii, Kraków 2006, s. 88-89. 
zebrano 1,8 mln podpisów, które inicjatorzy ruchu w Niemczech: Dieter Grohmann, Eva-Maria Kiklas oraz Christian Weisner przekazali na ręce bpa Karla Lehmanna, ówczesnego przewodniczącego Niemieckiej Konferencji Biskupów oraz Centralnemu Komitetowi Katolików Niemieckich. W styczniu 1996 r. doszło w Düsseldorfie do spotkania przedstawicieli pochodzących ze wszystkich 27 diecezji, gdzie zawiązane zostały grupy ruchu Wir sind Kirche. Kolejne działania związane były z postulowanym dostępem kobiet do stałego diakonatu oraz kapłaństwa, a w 1998 r. ruch Wir sind Kirche stanął po stronie niemieckich biskupów w sporze z papieżem o prowadzone przez podmioty kościelne poradnictwo dla kobiet ciężarnych.

Trudno oszacować potencjał niemieckiej części ruchu Wir sind Kirche na podstawie liczby członków, gdyż deklarując swój otwarty charakter nie wymaga on sformalizowania przynależności. W porównaniu z niewielką Austrią znacząca jest przywoływana liczba 1,8 mln sygnatariuszy apelu założycielskiego. Z pewnością jednak czynnikiem, który przysparza kontestatorom popularności i głosu wśród opinii publicznej są postaci teologów, od lat krytycznie nastawionych do Kościoła hierarchicznego, którzy szczególnie za pontyfikatu Jana Pawła II odcisnęli swoje piętno na dyskusjach wokół reform katolicyzmu. Sformułowany u początków omawianej fali krytyki Kościoła w Niemczech pogląd jej polskiego obserwatora zachowuje do dziś aktualność: „odgłosy burzy, jaka przetacza się przez Kościół nad Renem, będą coraz silniej docierać do Kościołów siostrzanych. Rola niemieckiej teologii jest zbyt kluczowa, aby mogło być inaczej. Dzięki wielkiej tradycji i kulturze humanistycznej, szczególnie filozoficznej, dzięki gruntowności badań Niemcy mają szczególny charyzmat nauki w Kościele i kulturze światowej. Z kręgu kultury języka niemieckiego pochodzi wielu największych teologów Kościoła - i wielu jego największych krytyków"10. Eugen Drewermann, Hans Küng czy obecny od początków działania Wir sind Kirche w Niemczech, znany z radykalnych poglądów i niesubordynacji Jacques Gaillot, usunięty z diecezji Evreux „czerwony biskup" to osobowości, z pominięciem których trudno byłoby opisać debatę o Kościele w Niemczech.

Pochodzący ze Szwajcarii Hans Küng należał wraz z Josephem Ratzingerem do najmłodszych doradców uczestniczących w obradach Soboru Watykańskiego II. Wykształcony na Uniwersytecie Gregoriańskim w Rzymie oraz paryskiej Sorbonie, po święceniach kapłańskich kontynuował prace naukową w Münster i Tybindze. Gorący zwolennik reform soborowych, z czasem wykroczył poza ramy katolickiej ortodoksji, a po bezskutecznych upomnieniach w 1979 r. deklaracja Kongregacji Nauki

${ }^{10}$ D. Oko, Przełom, wyzwanie i szansa, Kraków 1998, s. 74. 
Wiary pozbawiła go prawa nauczania jako teologa katolickiego. Hans Küng kontynuował pracę jako niezależny teolog, jest również twórcą fundacji na rzecz dialogu międzyreligijnego i międzykulturowego Weltethos, pod której auspicjami w 2012 r. powołano na Uniwersytecie w Tybindze Weltethos-Institut. Wysuwane przez Künga wątpliwości, które go oddaliły od oficjalnej wykładni Kościoła, dotyczyły nieomylności papieża, celibatu oraz możliwości święceń kapłańskich kobiet; wypowiadał też kontrowersyjne tezy w kwestiach związanych z przerywaniem ciąży i zapłodnieniem in vitro. Zarzucał Janowi Pawłowi II odejście od reform Vaticanum II oraz próbę eklezjalnej i politycznej restauracji potęgi Kościoła w duchu przedsoborowym. Punktował nie tylko problemy Kościoła, ale również próby ich maskowania przez hierarchię, w czym upatrywał przyczyn dezintegracji wspólnot kościelnych na poziomie parafii, borykających się z brakiem księży oraz kurczącą się społecznością wiernych. Szwajcarski teolog nie zmienił krytycznych poglądów wraz z objęciem Stolicy Apostolskiej przez Benedykta XVI, swego dawnego przyjaciela. Początkowo wiązał z nowym pontyfikatem nadzieje na zawrócenie Kościoła z drogi odejścia od reform i dialogu z innymi wyznaniami, później jednak pogłębił swą krytykę. Mimo rozmów z papieżem w cztery oczy, posunął się do określenia aktualnej sytuacji mianem „putinizacji Kościoła katolickiego"11, nie kryje swego rozczarowania działaniami „papieża afrontów"12, obawia się zniweczenia dokonań dialogu z Żydami, muzułmanami i anglikanami oraz konsekwencji utrzymywania zachowawczej i restauracyjnej linii w Kościele. Napisany przez Künga w 2010 r. list otwarty do biskupów świata podsumowuje pięć lat pontyfikatu Benedykta XVI w formie zaprzepaszczonych szans i zmarnowanych okazji do podjęcia dia$\operatorname{logu} \mathrm{z}$ innymi wyznaniami i religiami, ze współczesnym światem oraz wewnątrz samego Kościoła ${ }^{13}$. Mimo, iż Hans Küng wyraża w swych wystąpieniach przekonanie o istniejącej wciąż szansie „uratowania” Kościoła pod warunkiem powrotu na drogę wyznaczoną przez Jana XXIII i Sobór, głoszone przez niego postulaty wymknęły się poza ramy doktrynalnie akceptowalnych zmian, choćby w dziedzinie dopuszczalności celebrowania Eucharystii bez udziału duchownego ${ }^{14}$.

${ }^{11}$ Theologian Hans Küng on Pope Benedict, "A Putinization of the Catholic Church", "Spiegel Online International" 21 IX 2011, http://www.spiegel.de/international/world/theologian-hans-kueng-on-pope-benedict-a-putinization-of-the-catholic-church-a-787325-2.html

${ }^{12}$ Katolicka Agencja Informacyjna, Hans Küng zarzuca papieżowi „ostry kurs reakcyjny", 1 lutego 2009 r., http://ekai.pl/wydarzenia/swiat/x17913/hans-kung-zarzuca-papiezowi-ostry-kurs-reakcyjny

${ }^{13}$ List Hansa Künga ukazał się 16 kwietnia 2010 r., „The Irish Times”, tekst polski: „Tygodnik Powszechny” nr 18 z 2 maja 2010 r.

${ }^{14}$ Hans Küngs Strategie zur Durchsetzung von Reformen, „Passauer Neue Presse” 28.11.2011, cyt za: http://www.wir-sind-kirche.de/index.php?id=373\&id_entry=3706 
Suspendowany już w 1992 r. Eugen Drewermann, teolog i psychoanalityk, był księdzem katolickim diecezji Paderborn oraz profesorem dogmatyki miejscowego uniwersytetu. Autor licznych publikacji i niezwykle popularny wykładowca oraz prelegent, doszedł w swej krytyce do odrzucenia podstawowych dogmatów chrześcijańskich o bóstwie Chrystusa oraz zakwestionowania hierarchicznego ustroju Kościoła i wskazań etyki seksualnej. Daleko posunięta negacja sprawiła, że w odróżnieniu od Hansa Künga, którego poglądy przystawały jeszcze do teologii protestanckiej, przestał się mieścić nie tylko w konfesji katolickiej, ale i w chrześcijaństwie. Nawoływanie do „modlitwy o zanik Kościoła jako instytucji” ${ }^{15}$ nie przeszkodziło jego popularności jako autora koncepcji interpretującej religię przez pryzmat tzw. psychologii głębi. $W$ drewermannowskiej koncepcji na miarę New Age dopełnienie historyczno-krytycznej metody egzegezy biblijnej stanowiły zaczerpnięta z Zygmunta Freuda psychoanaliza i teoria archetypów Karla Gustawa Junga. Krytyka instytucji kościelnych oraz duchowieństwa, choć prowadzona z pozycji, którym z czasem coraz trudniej było nadać rangę naukowa, była komentowana m.in. przez bpa Waltera Kaspera jako wezwanie do samokrytycznej refleksji ${ }^{16}$. Radykalne poglądy doprowadziły Eugena Drewermanna w 2005 r. do decyzji o wystąieniu z Kościoła katolickiego. Z punktu widzenia postulatów ruchu Wir sind Kirche istotna jest jedna z wcześniejszych publikacji Drewermanna, pochodząca z 1989 r. „Duchowni. Psychogram ideału”, w której dopatrywał się negatywnego wpływu celibatu na osobowość duszpasterzy i stawiał tezę o konieczności radykalnej reformy Kościoła, bez której nie będzie on w stanie dotrzymać kroku współczesności.

Relacjonujący na gruncie polskim poglądy Eugena Drewermanna ks. Dariusz Oko docenił wartość jego krytyki jako wezwania do rewizji życia chrześcijańskiego - w wymiarze jednostkowym, ale i instytucjonalnym - pod kątem autentyczności, zgodności z modelami wynikającymi z pierwotnych źródeł oraz nauczania Kościoła. Nie odrzucił też, przerysowanej wprawdzie u Drewermanna, lecz ważnej roli psychologii, która $\mathrm{w}$ powiązaniu z socjologią i teologią może być pomocna w wyznaczeniu równowagi między wymaganiami wspólnoty/instytucji, a potrzebami oraz rozwojem jednostki. Dramatyczny przypadek Drewermanna zwrócił uwagę na potrzebę lepszego przyswojenia psychologii w badaniach i nauczaniu teologów: „Spotkanie z Drewermannem może obudzić Kościół i teologię z dogmatycznej drzemki, podobnie jak w XVI wieku przebudzał ich Luter. Oby tylko koszta tego przebudzenia, oby powstające i pozosta-

${ }^{15}$ D. Oko, Przełom, wyzwanie..., op. cit., s. 74.

${ }^{16}$ Ibidem, s. 92. 
jące podziały były jak najmniejsze ${ }^{\prime \prime 17}$. To ostatnie życzenie pozostaje raczej do dziś nierozstrzygnięte.

Zbieżność postulatów formułowanych przez znanych, choć obłożonych karami kościelnymi teologów z hasłami „ruchów ludowych” potęguje ich rezonans w opinii publicznej, przyciąga uwagę środków przekazu i pozwala popularyzować zarówno te, z całą pewnością, ponadprzeciętne indywidualności, jak i organizacje. Amerykański publicysta katolicki i biograf Jana Pawła II Georg Weigel, odpowiadając na list otwarty Hansa Künga, w pełen ironii sposób zwrócił uwagę na zabiegi teologa, od lat podtrzymującego swą popularność: „przyjaciel poprosił Pana pewnego razu na stronę i używając znanego wam francuskiego powiedzenia, stwierdził: 'Hans, zaczynasz za bardzo rzucać się w oczy'. Jako człowiek, który wynalazł nowy w skali globalnej typ osobowości: teolog-dysydent jako międzynarodowa gwiazda mediów, nie był Pan, jak przypuszczam, zbytnio przygnębiony udzielonym ostrzeżeniem. Już w 1963 r. był Pan zdecydowany wytyczyć dla siebie osobną ścieżkę; był też Pan na tyle bystry, by wiedzieć, że prasa światowa, zainteresowana szokującą i frapującą historią dysydenckiego księdza-teologa, odda w Pańskie ręce megafon, by usłyszeć Jego opowieśc."18 Z gromadzonego w ten sposób od lat potencjału korzysta dziś ruch Wir sind Kirche, mimo, że w publicznych wypowiedziach Hansa Künga nietrudno wychwycić powtarzające się nie tylko argumenty, ale i figury retoryczne czy porównania.

\section{Reakcje i komentarze}

Mimo radykalnych i sprzecznych z nauczaniem oraz praktyką Kościoła postulatów wytoczonych na forum publiczne przez platformę Wir sind Kirche, reakcja zwierzchników kościelnych w Austrii była łagodniejsza, niż w przypadku polemik z teologami-dysydentami. Zaskakujące, także dla samych inicjatorów ruchu, było poparcie uzyskane dzięki akcji gromadzenia podpisów. Marginalne były próby dezawuowania skali poparcia; przeważały reakcje umiarkowane, doceniające wysunięte postulaty, jeśli nie dla nich samych, to jako przejaw napięć i potrzeby otwartej dyskusji z udziałem świeckich oraz duchowieństwa. Brak gwałtownych reakcji był uzasadniony napiętą sytuacją austriackiego Kościoła po sprawie Gröera, a także nieco późniejszą sprawą bpa Kurta Krenna z diecezji St. Pölten, choć z drugiej strony, jak stwierdził ówczesny Nuncjusz Apostolski abp Donato

17 Ibidem, s. 94.

${ }^{18}$ G. Weigel, Zajadłość teologiczna. List otwarty do Hansa Künga, w: „Tygodnik Powszechny" nr 18 z 2 maja 2010 r. 
Squicciarini, odpowiedź na wszystkie postulaty zwarta jest w dokumentach Soboru Watykańskiego II oraz późniejszym nauczaniu Kościoła, aż po papieża Jana Pawła $\mathrm{II}^{19}$. Wnikliwy obserwator życia religijnego w Europie, austriacki teolog prof. Paul Zulehner ocenił fenomen ruchu jako wyraz dojrzałej świadomości katolików nad Dunajem, nie czekających tylko na odgórne impulsy. W podobnym duchu wypowiadali się działacze laikatu: Akcji Katolickiej oraz Katolickiej Rady Świeckich ${ }^{20}$.

Stanowczym krytykiem organizacji oraz postulatów Kirchenvolks-Begehren był wspomniany bp Kurt Krenn - postać budząca kontrowersje oraz otwarty sprzeciw w Wiedniu, gdzie był biskupem pomocniczym u boku kard. Hansa Hermanna Gröera, a później w powierzonej mu diecezji St. Pölten. Był on zdania, że akceptacja postulatów Kirchenvolks-Begehren ostatecznie i tak służyć ma dokonaniu rozłamu w Kościele ${ }^{21}$. Biskup ściągnął na siebie krytykę opinii publicznej niefortunnym porównaniem poparcia ruchu Kierchenvolks-Begehren do akceptacji w 1938 r. Anschlussu Austrii.

Umiarkowane reakcje były zapewne efektem wyczekiwania i kalkulacji, świadczyły o ostrożności i woli nie zatrzaskiwania drzwi prowadzących ku dialogowi z kontestującą częścią wiernych. Zdystansowaną, lecz pozytywną ocenę samego faktu powstania ruchu, jakiej dokonał nawet arcybiskup Wiednia Christoph Schönborn przełamał jego wielki poprzednik. Cieszący się ogromnym autorytetem, od 1985 r. emerytowany kardynał Franz König wyraził zdecydowaną dezaprobatę dla postulatów zniesienia celibatu, dopuszczalności święceń kobiet oraz kwestii etyki seksualnej, argumentując na rzecz wartości z nich płynących, które gubią się w obliczu ewolucji współczesnych sumień22. Oficjalne stanowisko Konferencji Biskupów sformułowane podczas obrad w dniach 7-9 listopada 1995 r. nie zawierało jednak polemiki z postulatami Kirchenvolks-Begehren, lecz odnosiło się do zaistnienia (czy raczej petryfikacji) samego zjawiska masowego ruchu domagającego się dyskusji o zmianach w Kościele. Biskupi zwracali uwagę, że inicjatywa przyciągnęła wielu aktywnych chrześcijan, pragnących rzeczywiście pozytywnych zmian. „Nie znaczy to, że chcemy ustępować przed monopolem na prawdę pojedynczych grup"23. Biskupi zdecydowali podjąć i utrzymywać kontakty z inicjatorami ruchów oraz grupami i osobami poczuwającymi się do opozycji wobec Kościoła, a także do prowadzenia otwartych dyskusji w małych i większych wspól-

19 T. Mirończuk, Wptyw ruchu..., op. cit., s. 96.

${ }^{20}$ Ibidem, s. 109-110.

${ }^{21}$ Ibidem, s. 108.

${ }^{22}$ Ibidem, s. 98-99.

${ }^{23}$ Osterreichische Bischofskonferenz, 7-9. November 1995, Erklärung, http://www. bischofskonferenz.at/content/site/dokumente/presseerklaerungen/1995/index.html, cyt. za: T. Mirończuk, Wptyw ruchu..., op. cit., s. 101. 
notach różnych szczebli, celem poznania oraz rozwiązywania zaistniałych problemów i wątpliwości. Zasadniczy motyw tych działań miał przybliżyć odpowiedź na fundamentalne pytanie o aktualny cel i sens misji Kościoła w konkretnych realiach austriackiego "tu i teraz”. Efektem tych działań stała się inicjatywa „Dialog für Österreich”, podejmująca tematykę fundamentów wiary, adaptacji zadań duszpasterskich oraz wyzwań społeczno-politycznych stojących przed Kościołem w Austrii. Opublikowane po wiosennej sesji episkopatu w 1997 r. dokumenty odnosiły się do odnowy w Kościele, zadań wybranych na nową kadencję rad duszpasterskich, a także kwestii azylantów, sekt i zagadnień technologii genetycznych. W części stanowiącej reakcję na zaistniały kryzys, zwierzchnicy ponowili podstawowe pytania o kształt działalności Kościoła: treść, sposób oraz adresata jego przekazu. Charakterystyczna była forma, w jakiej starano się podjąć te refleksje: zaplanowany na 1998 r. ogólnokrajowy zjazd delegatów wyłanianych w autonomiczny sposób przez diecezje, choć nie miał posiadać rangi synodu, otwierał szerokie możliwości dialogu z udziałem laikatu.

\section{Pfarrer-Initiative}

W odróżnieniu od ruchów kontestacyjnych laikatu w Kościele katolickim Austrii i Niemiec, zainicjowane w 2006 r. przez wiedeńskiego księdza Helmuta Schüllera działania organizacji Pfarrer-Initiative są ściśle związane z pracą duchowieństwa. Kwestie przedstawione po raz pierwszy przez dziewięciu proboszczów podczas konferencji prasowej 25 kwietnia 2006 r. zawierały propozycje zmian, które zaradziłyby brakom $\mathrm{w}$ obsadzie wielu parafii i konieczności ich łączenia oraz sprawowania posługi przez jednego księdza w wielu miejscach. Sugerowano zwiększenie udziału świeckich $\mathrm{w}$ podejmowaniu odpowiedzialności za parafie, ze sprawowaniem liturgii włącznie. Wśród pierwszych postulatów znalazła się też reforma kościelnego prawa małżeńskiego dotycząca osób rozwiedzionych. Rozszerzany w kolejnych latach wraz z rosnącą liczbą przyłączających się do ruchu sygnatariuszy katalog postulatów zawiera wezwanie do zwiększenia wpływu świeckich i duchownych lokalnego Kościoła na obsadę stanowisk biskupów, co stanowi wynik austriackich doświadczeń z wcześniejszych dekad, gdy - zdaniem kontestatorów - najważniejszym kryterium wyboru zwierzchników była wierność Rzymowi. W dokumentach publikowanych przez Pfarrer-Initiative w ostatnich latach znalazły się tak daleko idące postulaty, jak dopuszczalność świeceń kobiet oraz żonatych mężczyzn, pełnienie funkcji przełożonych parafii przez świeckich („,dzięki 
nowemu rozumieniu kapłaństwa"24), powszechny dostęp do sakramentu Komunii św., sprawowanie Eucharystii bez księdza oraz głoszenie kazań przez świeckich.

Sześć lat od powstania, wg danych z listopada 2012 r., Pfarrer-Initiative liczyła w Austrii 425 członków (księży i diakonów) i była wspierana przez 81 osób stanu duchownego oraz 2908 wiernych świeckich. Podobnie jak Wir sind Kirche, organizacja rozszerzyła pole swego oddziaływania na teren Niemiec, gdzie w kilku diecezjach na południu kraju (Würzburg, Monachium, Augsburg, Rottenburg-Stuttgart, Limburg oraz Kolonia) zawiązane zostały lokalne grupy. Na podkreślenie zasługuje fakt, że średnia wieku osób popierających przekracza 50 rok życia, co pozwala interpretować zjawisko jako charakterystyczne dla "pokolenia Soboru”, podczas gdy wśród najmłodszych roczników duchowieństwa nie znajduje ono podobnego zainteresowania i akceptacji ${ }^{25}$. Pfarrer-Initiative znalazła zainteresowanie także wśród duchowieństwa katolickiego w Szwajcarii, gdzie 17 września 2012 r. sformułowany został dokument inicjujący dyskusję $^{26}$, a liczba jego sygnatariuszy oraz sympatyków jest systematycznie aktualizowana.

Sprzeciw wobec administrowania przez jednego księdza kilkoma parafiami i konieczności odprawiania wielu nabożeństw jednego dnia uzasadniany jest troską o autentyczne, bliskie wiernym duszpasterstwo, które z braku czasu zastępuje pospieszna obsługa. Jednak dyktowane kategorycznym tonem przez Pfarrer-Initiative środki zaradcze są nie do pogodzenia z ustrojem Kościoła katolickiego oraz obowiązującym prawem kanonicznym. Artykułowane wprost wezwanie do nieposłuszeństwa godzi w fundamentalne zasady rządzące Kościołem. Reakcje przełożonych na hasła głoszone przez ks. Helmuta Schüllera oraz szybko rosnącą grupę jego zwolenników były od początku stanowcze. Nie negują diagnozowanych problemów ani potrzeby dyskusji i zmian, proponowane środki traktują jednak - jak ordynariusz Graz bp Egon Kapellari - jako dobrane selektywnie bez uwzględnienia całościowego obrazu Kościoła w Austrii ${ }^{27}$. Mimo kategorycznych sformułowań stosowanych przez Pfarrer-Initiative, $\mathrm{w}$ prowadzonych rozmowach, m.in. z kard. Christophem Schönbornem w archidiecezji wiedeńskiej, księża Helmut Schüller, Hans Bensdorp, Gerald Gump uważają się za pełnoprawnych i odpowiedzialnych członków

${ }^{24}$ Wezwanie do niepostuszeństwa, 19 czerwca 2011 r., (tekst w języku polskim) http:// www.pfarrer-initiative.at

${ }_{25}$ Zukunftsangst ist schon da. Interview mit dem Sprecher der Pfarrer-Initiative, Dekan Joachim Bayer, w: „Würzburger Katholisches Sonntagsblatt”, nr 18, 29. April 2012, s. 10.

${ }^{26}$ Initiativtext, http://pfarrei-initiative.ch

27 Bischof Kapellari tritt Aufrufvon Priestern zu Ungehorsam scharfentgegen, 29. Juni 2011, http://www.erzdioezese-wien.at/content/artikel/a26190 
wspólnoty Kościoła ${ }^{28}$. Po drugiej stronie stołu rozmów jest zgodność co do diagnozowanych problemów austriackiego katolicyzmu, jednak proponowane środki zaradcze przybliżają ewentualność zastosowania kar dyscyplinujących wobec kontestujących duchownych.

Dokumenty powstałe w toku działalności niemieckiego odłamu Pfarrer-Initiative zawierają bardziej wyważone opinie i propozycje zmian. Choć i w nich znaleźć można daleko idące pomysły dotyczące kapłaństwa, potraktowane zostały raczej drugorzędnie. Punkt wyjścia stanowi raczej kryzys autorytetu Kościoła spowodowany nadużyciami i skandalami, które dotknęły w ostatnich latach jego społeczność w Niemczech. Memorandum profesorów teologii z 4 lutego 2011 r., podpisane przez 311 osób, w tym 240 z krajów niemieckojęzycznych, zwraca uwagę, że brak dyskusji może przyczynić się do pogłębienia kryzysu, mierzonego odejściami z Kościoła lub zamykaniem się w prywatności ${ }^{29}$. Próby odwołań do rozstrzygnięć sumienia były dyskutowane wcześniej, choćby w kwestii ponownych związków małżeńskich, a cały dokument, nie ferując z góry gotowych rozwiązań, wzywa do położenia silniejszego akcentu na odpowiedzialność wszystkich członków Kościoła.

\section{Wnioski}

Dynamika towarzysząca inicjowaniu i organizacji katolickich ruchów kontestacyjnych w Austrii oraz Niemczech wskazuje na znaczną zbieżność artykułowanych przez nie diagnoz i postulatów z poglądami i oczekiwaniami wielu wiernych świeckich oraz duchownych. Nie były one jedynie reakcją na ujawnienie „,sprawy Gröera”, gdyż od początku manifestowały szerszy zakres postulatów, niż tylko zaradzenie nadużyciom obyczajowym.

Wyważona reakcja na krytykę oraz podjęcie szerokiego dialogu z ruchami oddolnymi laikatu przynosi rezultaty pozwalające z dłuższej perspektywy pozytywnie oceniać sytuację katolicyzmu w Austrii. Oświadczenie wydane przez Konferencję Biskupów Austrii na zakończenie jesiennego zgromadzenia plenarnego w 2011 r. zawiera m.in. następującą diagnozę: „Kościól, także w naszym kraju, jest o wiele bardziej żywotny, niż jest to często postrzegane czy przedstawiane. Także tu zachowują aktualność słowa proroka Izajasza: ‘Oto Ja dokonuję rzeczy nowej: pojawia się właśnie. Czyż jej nie poznajecie?’ Starania o bliskie

\footnotetext{
${ }^{28}$ Reaktion aus Wien, 14. Oktober 2011, http://www.pfarrer-initiative.at

${ }_{29}$ Memorandum von Theologieprofessoren und -professorinnen zur Krise der katholischen Kirche, 4 Februar 2011, http://www.memorandum-freiheit.de
} 
codzienności i misyjne duszpasterstwo wzrosły w diecezjach Austrii i będą dalej intensyfikowane" ${ }^{\prime 30}$.

Sformalizowanie działania ruchów kontestacyjnych pozwala w uchwytny sposób szacować ich dynamikę, co jednak ważniejsze, ułatwia dialog z hierarchią oraz instytucjami kościelnymi. Bez wątpienia petryfikacja krytyki i sprzeciwu w ramach powstałych ruchów służy krystalizacji stanowisk oraz ułatwia diagnozowanie sytuacji społecznej i pastoralnej w łonie austriackiego i niemieckiego katolicyzmu. W przeciwnej sytuacji - „pełzającej kontestacji” - nie byłaby możliwa szybka reakcja zwierzchników kościelnych w formie oficjalnych dokumentów oraz programów dialogu i odnowy.

Zgoła odmiennie traktowany jest ruch Pfarrer-Initaitive, którego postulaty, bezkompromisowa forma ich artykułowania oraz zasadnicza sprzeczność między zasadą posłuszeństwa a podejmowanymi działaniami i postawami stawia w perspektywie możliwego rozłamu. Choć w oficjalnych wypowiedziach austriackich biskupów dostrzegalna jest wola poszukiwania pozytywnych rozwiązań, eskalacja radykalnych form wypowiedzi ze strony liderów Pfarrer-Initiative trafić może na podatny grunt buntu przeciw Kościołowi.

W ocenie protestu duchownych, jakiego przejawem jest Pfarrer-Initiative, także w Niemczech, konieczne jest uwzględnienie obaw przed zmianami będącymi konsekwencją zmniejszania się liczby placówek duszpasterskich. Łączenie parafii czy brak stałego miejsca spotkań i nabożeństw stanowi zagrożenie dla egzystencji wspólnoty, w wymiarze pastoralnym, ale również społecznym. Zakres obowiązków - nie tylko administracyjnych - jakimi są obciążenie księża, nie pozostaje bez wpływu na ich pracę.

W nawiązaniu do polskiego kontekstu warto wspomnieć tezę Tadeusza Bartosia ${ }^{31}$ o potrzebie wycofania się religii do sfery prywatnej, gdyż wartości głoszone przez Kościół i chrześcijaństwo zostały przyjęte do kanonu współczesnego prawa i porządku ustrojowego. Wprawdzie wniosek, do którego doszedł autor - iż czas Kościoła minął bezpowrotnie, jest jednostronny, ale uwagi o konieczności poszerzenia przestrzeni dyskusji (a przy tym katalogu wątpliwości) oraz otwartości w podejściu do nich, jak najbardziej aktualne także w polskiej rzeczywistości.

Polska perspektywa spojrzenia na postulaty podnoszone przez krytyczne wobec Kościoła ruchy świeckich i duchownych obszaru niemieckojęzycznego ukazuje wielorakie różnice wynikające z tradycji oraz lokalnej

${ }^{30}$ Wortlaut der Presseerklärungen der Herbstvollversammlung der Österreichischen Bischofskonferenz vom 7. bis 10. November 2011 in Salzburg, http://www.bischofskonferenz.at/content/site/dokumente/presseerklaerungen/2011/article/499.html

31 T. Bartoś, Wir sind Kirche, w: "Znak” nr 12/2010. 
praktyki. Nie znaczy to jednak, że wskazywane przez nich problemy są całkowicie obce lub w przyszłości nie staną się udziałem także polskiego katolicyzmu. Warto już dziś przeanalizować podłoże i argumenty podnoszone przez krytycznych chrześcijan nad Dunajem i Renem, traktując doświadczenie tamtejszych Kościołów nie tylko jako przestrogę, ale także jako wskazówkę.

\section{Zusammenfassung}

Das Ende des politischen Katholizismus, die Periode der kritischen Einstellung an der Wende von den sechziger zu den siebziger Jahren und die fortschreitenden Prozesse der Laizisierung sowie die Veränderungen auf der Karte des religiösen Lebens im wiedervereinigten Deutschland bilden den Hintergrund für die Entstehung von Bewegungen von unten, die radikale Forderungen für Reformen der Institutionen der Römisch-Katholischen Kirche und ihrer Lehre aufstellen. Aus der Sicht der Kirche selbst sind die Erfahrungen mit den Folgen der Reformation von Bedeutung, die Kultur des Dialogs, auch die des ökumenischen, wie auch die fundamentalen Reformen des Zweiten Vatikanischen Konzils. In den deutschsprachigen Ländern - der Heimat großer Theologen und Reformatoren - entwickelten sich in den jüngsten Jahrzehnten ausgeprägte Strömungen einer radikalen Kritik und der Forderung nach Veränderungen der kirchlichen Lehre. Die im Jahre 1995 entstandene Bewegung Wir sind die Kirche oder die Pfarrer-Initiative, die ihre Aktivität bis auf das Jahr 2006 zurückführt, unterziehen das Funktionieren der kirchlichen Strukturen einer Kritik und fordern Veränderungen, die sich nicht allein auf den Versuch beschränken, den negativen Folgen der Säkularisierung zu begegnen, sondern auch eine Revision des Kirchenrechts sowie der jahrhundertealten Tradition der Kirche ins Auge fassen. Die kirchliche Obrigkeit reagiert darauf mit dem Versuch eines Dialogs, aber auch mit spektakulären Ermahnungen, sogar von seiten Papst Benedikts XVI. Das Ausmaß der Probleme, auf die die Kritiker hinweisen, verlangt, sie nicht nur als Verletzer der Disziplin zu betrachten, sondern auch als ein Element, das den innerkirchlichen Dialog sowie die Beziehungen der Kirche zur Gesellschaft stimuliert. 